\title{
Strategic Guidelines for the Modernization and Diversification of the Resort Town's Economy
}

\author{
Ivan Antipin ${ }^{1, *}$, and Roman Tikhonchuk ${ }^{2}$ \\ ${ }^{1}$ Ural State University of Economics, 620144 Ekaterinburg, Russia \\ ${ }^{2}$ Administration of the city of Yevpatoria, 297408 Yevpatoria, Russia
}

\begin{abstract}
The article is devoted to the study of strategic guidelines for diversification of production and modernization of the economy of a resort town on the example of the urban district of Yevpatoria of the Republic of Crimea. The competitive advantages, distinctive features of the draft Strategy for the socio-economic development of the urban district of Yevpatoria of the Republic of Crimea, including strategic guidelines for the modernization and diversification of the city's economy, necessary for its further development as a resort city, are formulated. The research methodological framework is based on the theoretical principles of strategic management, regional and municipal economy. This study is based on a comprehensive analysis of the draft strategy for the socioeconomic development of the urban district of Yevpatoria of the Republic of Crimea by using a combination of methods: logical, dialectical, and also causal ones. The article is of interest to researchers, practitioners, including state and municipal officials dealing with the formation (development and updating), as well as the implementation and control over the implementation of strategies for the socio-economic development of territories and other stakeholders.
\end{abstract}

\section{Introduction}

Strategic planning refers to a relatively new type of planning for the development of various objects, including cities. In Western European countries, interest in strategic planning on the part of state and local authorities appeared in the mid-1980s, and in the United States, strategic planning methods began to be used approximately from the beginning of the 1970 s $[1,2,3]$.

There are a lot of definitions of strategic planning in the scientific literature. Strategic planning is a process in which a city as an integral system positions itself in relation to other cities, creates an image of its future and develops the necessary actions to achieve it. This image defines the main targets, main directions of movement and gives the city impetus and energy.

At the same time, strategic planning acts as the practical activity associated with the development of strategic decisions, the implementation of which ensures the development and effective functioning of individual industries (areas) and forecasting objects in the long

\footnotetext{
*Corresponding author: aia87@mail.ru
} 
term. The result of this activity is the strategic planning document (strategy, strategic plan, etc.), which integrates the interdependent general plan, mission, main development goals, internal resources, methods, methods and organizational actions that ensure the achievement of the desired boundaries and goals and progress in the chosen direction into a certain agreed whole.

Strategic urban development planning is a modern type of "development planning" focused on the priority use of internal material, financial, labor and other resources and potentials, upbuilding the competitive advantages of cities, increasing their attractiveness for investors, firms, organizations, and the population [4].

Summing it up, it should be noted that strategic planning of urban development is a versatile, complex process in which strategy developers position the city in relation to other cities, determine possible options (scenarios) for its future and develop the necessary actions to achieve the desired goals and objectives of long-term development.

\section{Materials and Methods}

Actor-network theory is widely used in the practice of strategic planning, which also helps to shed light on the relationship between strategic planning and inclusive and participatory public administration [5].

In different countries, one or another theory of regional planning may dominate. It depends on the level of economic development, the alignment of political forces or the priorities of modern development. For example, analyzing the evolution of the planning system in Iran, M. Pajoohan notes that in the first three stages, regional planning was considered as a resource development tool. Subsequently, the theory of regional welfare and the theory of uneven regional development came to the foreground, and at the present stage the regionalism of entrepreneurship has taken the predominant place [6].

G. Heimpold analyzes how the priorities of regional strategies in the Czech Republic, Hungary and Poland after joining the European Union have changed, and whether modern regional strategies give priority to growth goals or focus on the goal of equalization [7]. The scientific literature emphasizes the presence of certain contradictions between theoretical elaboration and the actual practice of planning. It is noted that theoretical models are not always applied in practice and their success depends on how research scenarios in urban or regional planning take into account the values of stakeholders, and not only rely on expert judgment and analysis [8]. For the Russian Federation, despite the undoubted success in improving the strategic planning processes, the issues of studying their existing shortcomings remain relevant $[9,10]$. Forecasting the effectiveness of socioeconomic transformations in territorial systems, including cities, arises interest with modern researchers [11].

This study of strategic guidelines for the modernization and diversification of the resort city's economy is based on a comprehensive analysis of the draft strategy for the socioeconomic development of the urban district of Yevpatoria of the Republic of Crimea by using a set of methods: logical, dialectical, and also cause-and-effect.

\section{Results and Discussion}

According to clause 33 of Article 3 of the Federal Law of June 28, 2014 No. 172-FZ "On Strategic Planning in the Russian Federation", the strategy of socio-economic development of a municipality is a strategic planning document that defines the goals and objectives of municipal management and socio-economic development of the municipality for long-term period. 
Various circumstances, including the transition of the Republic of Crimea to the Russian Federation, did not allow the city of Yevpatoria to update the strategy of its socioeconomic development until 01.01.2019. However, by the Order of the Head of the municipal formation of the city of Yevpatoria of the Republic of Crimea dated 11/18/2019. 02-07 / 35, the Strategic Planning Committee was created and, accordingly, work on updating the strategy of socio-economic development began.

The strategy of socio-economic development of the municipal formation of the urban district of Yevpatoria of the Republic of Crimea until 2035 (hereinafter referred to as the Strategy) is a fundamental document of strategic planning that defines the goals and objectives of municipal administration, priority directions of socio-economic development of the municipal formation for the long term.

The main strategic goal of the development of Yevpatoria is strengthening the competitiveness of Yevpatoria as a resort, tourist, historical, cultural, scientific and business center of the Republic of Crimea and Russia, a city with a high quality of life for present and future generations of citizens.

To achieve the main strategic goal, 5 priority directions have been identified:

Development of a health resort complex and tourism infrastructure;

Modernization of the economy, diversification of production and improvement of conditions for private business. Formation of investment attractiveness;

Meeting modern requirements for the level and quality of housing and communal services;

Improving the social sphere. Creation of an environment favorable for life;

Improving territorial and extensional development.

Within the framework of the second priority area "Modernization of the economy, diversification of production and improvement of conditions for private business. Formation of investment attractiveness "three strategic goals have been defined:

1. Creation of conditions for attracting investments into the city's economy and ensuring the city's competitiveness in the investment market;

2. Development of the sphere of small and medium-sized businesses as one of the factors of socio-economic development and ensuring a consistently high level of employment of the population;

3. Increasing the revenue potential of the budget of the municipal formation of the urban district of Yevpatoria of the Republic of Crimea due to the effective use of municipal property.

To achieve the strategic goal "Creation of conditions for attracting investments into the city's economy and ensuring the city's competitiveness in the investment market", it is necessary to solve the following tasks:

1. Creation and development of infrastructure to support the main sectors of the city's economy, optimization of the distribution of industrial facilities.

2. Increasing the investment attractiveness of the city, supporting the implementation of infrastructure and investment and innovation projects.

3. Elimination of administrative barriers and restrictions for the development of investment activities. Ensuring the implementation of measures of state support for the subjects of investment activities, implementing investment projects.

4. Creation of favorable conditions on the territory of the municipality for the development of international and interregional, inter-municipal cooperation with cities of foreign countries and regions of Russia.

At the first stage of the implementation of the Strategy, the priority area for improving the investment potential will be the elimination of infrastructure restrictions at the expense of the federal budget, the formation of measures for the subsequent expansion of sources of financing for infrastructure projects. 
Effective interaction of local governments and private business (investors), based on the achievement of mutual interests, is one of the most important conditions for sustainable socio-economic development of the urban district, increasing investment and business activities, and the development of urban infrastructure.

An increase in the volume of investments in fixed assets is being planned and the development of the main sectors of the city's economy is expected through the implementation of the following investment agreements, memorandums, contracts.

The main measures to improve the investment attractiveness of the city are:

1. formation and promotion of the investment image of the urban district;

2. development of the infrastructure necessary for the implementation of investment projects;

3. creation of the most favorable investment climate;

4. an increase in the volume of funds raised from the federal budget and federal development institutions;

5.creation and development of legislative, organizational, infrastructural and information support for investment activities of the urban district, provision of measures of municipal support for investment activities;

6. creation of an administrative environment favorable for investments, reduction of bureaucratic and administrative barriers for organizing business and investment in production;

7. formation of investment sites for the implementation of investment projects;

8. creation of the most favorable conditions for the development of small and mediumsized businesses; assistance in the implementation of public-private (municipalprivate) partnership projects on the territory of the urban district;

9. attracting foreign investment, developing foreign economic activity, strengthening international cooperation;

10. mobilization of investment resources of the urban district and ensuring their effective use through the formation of municipal programs for the implementation of priority and socially significant areas of development of the urban district.

The main strategic results of the implementation of the planned activities (by the end of 2035) have been identified:

1. Achievement of the volume of shipped goods of own production, works and services performed on their own by organizations other than small businesses up to 3300.8 million rubles.

2. Growth of investments in fixed assets up to 2,210 million rubles, including up to 17,190 rubles per capita;

3 . The number of investment projects implemented on the territory of the municipality 23 units;

4. The number of agreements signed with cities of foreign countries - 14 units;

5. The number of agreements signed with the regions of the Russian Federation - 45 units.

The mechanisms for the implementation of the priority area of the strategic goal "Creation of conditions for attracting investments into the city's economy and ensuring the city's competitiveness in the investment market" are:

1.municipal program "Economic development and formation of the investment portfolio of the municipal formation of the urban district of Yevpatoria of the Republic of Crimea";

2. state program "Economic development and innovative economy";

3. investment agreements, memorandums, contracts;

4. inter-municipal, inter-regional and international agreements. 


\section{Conclusion}

The draft strategy for the socio-economic development of the urban district of Yevpatoria of the Republic of Crimea has undoubtful practical significance, due to the fact that it is a viable, not a formal ("framework") document, as well as a certain scientific novelty, distinctive features from similar documents of other municipalities. Some distinctive features, competitive advantages of the Strategy:

1. Clear structure of the document. Absolutely all sections that should be in such documents have been highlighted.

2. Conceptual foundations have been formulated. The mission, the main goal and the system of strategic goals and objectives have been determined.

3. Each of the priority areas has a unified structure, which ensures the clarity and unified logic of the document.

4. A mechanism for implementing the strategy, including a mechanism for monitoring, evaluating effectiveness, and adjusting has been developed.

In the developed document, among other things, the strategic guidelines for the modernization and diversification of the economy of the Yevpatoria urban district, which are necessary for its further development as a resort city, have clearly been worked out.

\section{References}

1. Local authorities and the market economy, Lessons from the Western European experience (1996)

2. Socially oriented local government. Experience of German cities for Russia (1999)

3. E.G. Animitsa, N.Yu. Vlasova, Development strategy of Yekaterinburg: goals, objectives, directions, implementation mechanisms: Abstracts. report and mess. interregion. scientific-practical seminar (2000)

4. E.G. Animitsa, N.Yu. Vlasova, Graduate studies (2010)

5. J. M. Bryson, B. C. Crosby, J. K. Bryson, International public management journal, 12(2), 172 (2009)

6. M. Pajoohan, Journal of Regional and City Planning, 30(2), 102 (2019)

7. G. Heimpold, Review of regional studies, 28(1), 1 (2008)

8. U. Avin, R. Goodspeed, Journal of the American Planning Association, 1 (2020)

9. Ya.P. Silin, E.B. Dvoryadkina, I.A. Antipin, Manager, 9(6), 2 (2018)

10. Ye.B. Lenchuk, Innovations, 2(256), 24 (2020)

11. A.G. Shelomentsev, Forecasting the effectiveness of socio-economic transformations in territorial systems, 310 (2008) 